\title{
ホワイトカラーの家族生活・個人生活に おける生活時間構造
}

(「だんらん」の研究・その 2)

\section{1.はじめに}

最近, 集合住宅の設計に於ては, 従来の DK 型から L 空間を含んだ型への展開が現実的課題となり，それに応 えた調查研究もこれまでいくつか行なわれてきている。 しかしながら，これらの研究に於て用いられた方法論 は，いずれも従来の「住み方研究」をそのままの踏襲し たものであり，結果は「だんらんを 6 帖で行なうものが …...\%」といった現象的把握に止まっていて，L空間の 住生活的観点からの把握, 即ち, 肝心の「だんらん」の 分析についてはきわめて不充分であったと云わざるを得 ない。

本研究は「住生活におけるコミュニケーションとプラ イバシー，(「だんらん」の研究)」(論文報告集，第 148 号，1968 年 6 月）にひきつゔいて，「だんらん」の質的 解明と，それの住空間との対応関係の把握に接近するた め, 次の 3 点を研究課題として設定した。

(1) 家族生活，個人生活の内容と，これを規定する時 間的制約 (労働時間) ・肉体的制約 (疲労) 等，一般 的要因之の対応関係の究明。

(2) 家族生活，個人生活を構成する主要な行動形態の 追求，及びこれらの行動が組みあわされて成立する 家族生活の型，個人生活の型の設定。

(3) 家族生活の型，個人生活の型と住宅間との対応関 係の究明。

なお，ここでは「だんらん」に対するある種の先入感 をできるだけ取り除くため，「だんらん」を「家族生活」 として表現している。

\section{2. 調查, 集計の方法}

本研究では，集合住宅居住世帯の中でも，比較的，家 族生活や個人生活を発展させる条件をもっている階層一 経済的にはかなりのゆとりがあり，しかも分譲アパート の購入にみられる様に，住意識の点でも新しい観点にた つ上層のホワイトカラーを，特に調査対象として有意に

* 京大助乎 $* *$ 住宅公団技師 $* * *$ 大阪府技師 (昭和 44 年 7 月 16 日本稿受理. 討論期限昭和 44 年 4 月末日)

$\begin{array}{lllll}\text { 正会員 } & \text { 広 } & \text { 原 } & \text { 盛 } & \text { 明* } \\ \text { 正会員 } & \text { 竹 } & \text { 本 } & \text { 俊 } & \text { 平** } \\ \text { 正会具 } & \text { 松 } & \text { 原 } & \text { 徹 } & \text { 雄*** }\end{array}$

選んだ。これは，より分化したかたちでの家族生活や個 人生活が，そこに形成され定着しているかもしれないと いう期待をもったからであり，また調査技術上からも， 末分化の段階のものよりは，既に顕在化した段階の方が 把握し易いと判断したためである。

調査は 1967 年 10 月に若干の面接予備調査を行のたの ち，1968 年 2 月 6 日〜13 日の 7 日間，千里ニュータウ ンと香里団地のフラット，ポイント，メゾネットのうち 最大規模のものをえらんで，各戸に世帯票と 15 才以上 の個人票からなるアンケートを配布し，記入後これを回 収するといら方式によって行った。調查世帯数は 777 世 帯, 15 才以上の調查対象者は 1762 人で，回収率は世帯 票 669 で $86.1 \%$ ，個人票 1379 で $78.1 \%$ ，であった。そ の内訳は<表 2-1>の通りである。

<表 2-1> 調査対象世带数 - 個人数一覧䒾

\begin{tabular}{|c|c|c|c|c|c|c|}
\hline \multirow{2}{*}{$\begin{array}{l}\text { 場 } \\
\text { 所 }\end{array}$} & \multirow{2}{*}{$\begin{array}{l}\text { 種 } \\
\text { 類 }\end{array}$} & \multirow{2}{*}{$\begin{array}{l}\text { 型 } \\
\text { 工 }\end{array}$} & \multicolumn{2}{|c|}{ 世 带 票 } & \multicolumn{2}{|c|}{ 個 人 票 } \\
\hline & & & 配布数 & 回収数 & 配 有数 & 回収数 \\
\hline \multirow{3}{*}{ 千 } & 公団貨貸 & $\mathrm{F} \cdot 3 \mathrm{DK}$ & 330 & 279 & 743 & 550 \\
\hline & \multirow{2}{*}{ 公団分踝 } & $\mathrm{F} \cdot 3 \mathrm{~L} \cdot \mathrm{DK}$ & 50 & 45 & 118 & 95 \\
\hline & & $\mathrm{F} \cdot 3 \mathrm{DK}$ & 112 & 98 & 234 & 194 \\
\hline \multirow{3}{*}{ 里 } & \multirow{3}{*}{ 公社分軹 } & $\mathrm{M} \cdot 4 \mathrm{DK}$ & 53 & 45 & 156 & 98 \\
\hline & & P.3 LDK & 32 & 25 & 65 & 54 \\
\hline & & $\mathrm{F} \cdot 3 \mathrm{LD} \cdot \mathrm{K}$ & 136 & 120 & 290 & 265 \\
\hline 香里 & 公団分镶 & $F \cdot 3 L D \cdot K$ & 64 & 57 & 156 & 123 \\
\hline & 計 & & $\begin{array}{c}777 \\
(100.0)\end{array}$ & $\begin{array}{c}669 \\
(86.1)\end{array}$ & $\begin{array}{c}1,762 \\
(100.0)\end{array}$ & $\begin{array}{l}1,379 \\
(78.1)\end{array}$ \\
\hline
\end{tabular}

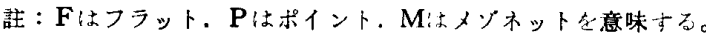

集計は全て IBM パンチカードによった。このため集 計カードは, 世帯票のカードと, 個人票のカードの 2 種 類を作成し，各々のカードの前半部分には共通項目を八 ンチし，後半部分には個別項目をパンチ寸る方法をとっ た。これは集計カードを完全に 2 種類にわけてしまう と，それらの間でのクロス集計が不可能となるので，ク ロス集計が必要と思われる項目は，各々のカードの共通 
<表 3-1> 調 查 対

\begin{tabular}{|c|c|c|c|c|c|c|c|c|c|c|c|c|c|c|c|c|c|c|c|c|c|c|c|}
\hline & \multirow[b]{2}{*}{ 計 } & \multicolumn{6}{|c|}{ 家 族 人 数 (人) } & \multicolumn{2}{|c|}{ 家 } & \multicolumn{3}{|l|}{ 族 } & \multicolumn{7}{|c|}{ 家族周期（第 1 子年令） } & \multicolumn{2}{|r|}{ 世 } & 带 & \\
\hline & & 2 & 3 & 4 & 5 & $\begin{array}{l}6 \\
?\end{array}$ & $\begin{array}{l}\text { 不 } \\
\text { 明 }\end{array}$ & $\begin{array}{l}\text { 夫 } \\
\text { 嬶 } \\
\text { 家 } \\
\text { 族 }\end{array}$ & $\begin{array}{l}\text { 世 } \\
\text { 代 } \\
\text { 家 } \\
\text { 族 }\end{array}$ & $\begin{array}{l}\text { 培 } \\
\text { 系 } \\
\text { 家 } \\
\text { 族 }\end{array}$ & $\begin{array}{l}\text { 烸 } \\
\text { 帣 } \\
\text { 揊 } \\
\text { 族 }\end{array}$ & 不 & $\begin{array}{l}2 \\
5\end{array}$ & $\begin{array}{c}6 \\
? \\
11\end{array}$ & $\begin{array}{c}12 \\
? \\
14\end{array}$ & $\begin{array}{c}15 \\
? \\
17\end{array}$ & $\begin{array}{c}18 \\
?\end{array}$ & $\begin{array}{l}\text { 子 } \\
\text { 供 } \\
+ \\
\text { V }\end{array}$ & 明 & $\begin{array}{l}\text { 管 } \\
\text { 理 } \\
\text { 職 }\end{array}$ & $\begin{array}{l}\text { 曹 } \\
\text { 門 } \\
\text { 職 }\end{array}$ & \begin{tabular}{l|} 
事 \\
枒 \\
職
\end{tabular} & $\begin{array}{c}\text { 貶 } \\
\text { 売サ } \\
-1 \\
1 \\
\text { ス } \\
\text { ス }\end{array}$ \\
\hline 鼓 & $\begin{array}{c}669 \\
100.0\end{array}$ & $\begin{array}{r}88 \\
13.2\end{array}$ & \begin{tabular}{r|}
185 \\
27.7 \\
\end{tabular} & $\begin{array}{r}294 \\
44.1\end{array}$ & $\begin{array}{r}63 \\
9.4\end{array}$ & $\begin{array}{r}21 \\
3.1 \\
\end{array}$ & $\begin{array}{r}18 \\
2.7\end{array}$ & $\begin{array}{r}585 \\
87.5 \\
\end{array}$ & $\begin{array}{r}42 \\
6.3\end{array}$ & $\begin{array}{r}18 \\
2.7\end{array}$ & $\begin{array}{r}13 \\
1.9\end{array}$ & \begin{tabular}{r|}
11 \\
1.6
\end{tabular} & $\begin{array}{r}195 \\
29.2 \\
\end{array}$ & $\begin{array}{r}175 \\
26.2 \\
\end{array}$ & $\begin{array}{r}42 \\
6.3\end{array}$ & $\begin{array}{r}22 \\
3.3\end{array}$ & $\begin{array}{r}84 \\
12.6\end{array}$ & $\begin{array}{r}104 \\
15.5\end{array}$ & $\begin{array}{r}47 \\
7.0\end{array}$ & $\begin{array}{r}258 \\
38.6 \\
\end{array}$ & $\begin{array}{r}157 \\
23.5 \\
\end{array}$ & \begin{tabular}{r|}
145 \\
21.7 \\
\end{tabular} & $\begin{array}{r}14 \\
2.1 \\
\end{array}$ \\
\hline 分譲住宅 & $\begin{array}{c}390 \\
100.0\end{array}$ & $\begin{array}{r}41 \\
10.5\end{array}$ & \begin{tabular}{r|}
109 \\
27.9 \\
\end{tabular} & $\begin{array}{r}182 \\
46.7\end{array}$ & $\begin{array}{r}37 \\
9.5\end{array}$ & $\begin{array}{r}9 \\
2.3\end{array}$ & \begin{tabular}{r|}
12 \\
3.1
\end{tabular} & $\begin{array}{r}350 \\
89.7 \\
\end{array}$ & $\begin{array}{r}22 \\
5.6\end{array}$ & $\begin{array}{r}5 \\
1.3\end{array}$ & $\begin{array}{r}6 \\
1.5\end{array}$ & \begin{tabular}{r|}
7 \\
1.8
\end{tabular} & $\begin{array}{r}87 \\
22.3 \\
\end{array}$ & $\begin{array}{r}130 \\
33.3 \\
\end{array}$ & $\begin{array}{r}26 \\
6.7\end{array}$ & $\begin{array}{r}18 \\
4.6 \\
\end{array}$ & $\begin{array}{r}56 \\
14.4\end{array}$ & $\begin{array}{r}46 \\
11.8\end{array}$ & $\begin{array}{r}27 \\
6.9\end{array}$ & $\begin{array}{r}184 \\
47.2 \\
\end{array}$ & $\begin{array}{r}85 \\
21.8 \\
\end{array}$ & $\begin{array}{r}68 \\
17.4 \\
\end{array}$ & $\begin{array}{r}6 \\
1.5\end{array}$ \\
\hline 筫貸住宅 & $\begin{array}{c}279 \\
100.0\end{array}$ & $\begin{array}{r}47 \\
16.8\end{array}$ & $\begin{array}{r}76 \\
27.2 \\
\end{array}$ & $\begin{array}{r}112 \\
40.1\end{array}$ & $\begin{array}{r}26 \\
9.3\end{array}$ & $\begin{array}{r}12 \\
4.3\end{array}$ & $\begin{array}{r}6 \\
2.2\end{array}$ & $\begin{array}{r}235 \\
84.2\end{array}$ & $\begin{array}{r}20 \\
7.2\end{array}$ & $\begin{array}{r}13 \\
4.7\end{array}$ & $\begin{array}{r}7 \\
2.5\end{array}$ & $\begin{array}{r}4 \\
1.4\end{array}$ & $\begin{array}{r}108 \\
38.7\end{array}$ & 16.1 & $\begin{array}{r}16 \\
5.7\end{array}$ & $\begin{array}{r}4 \\
1.4\end{array}$ & $\begin{array}{r}28 \\
10.0\end{array}$ & $\begin{array}{r}58 \\
20.8\end{array}$ & $\begin{array}{r}20 \\
7.2\end{array}$ & $\begin{array}{r}74 \\
26.5\end{array}$ & $\begin{array}{r}72 \\
25.8\end{array}$ & $\begin{array}{r}77 \\
27.6\end{array}$ & $\begin{array}{r}8 \\
2.9\end{array}$ \\
\hline
\end{tabular}

項目としてパンチしたためである。(しかし若干のミス により, 後になって一部にはクロス集計できないものも 生じた）

なお集計カードは 80 カラム (項目) 11 カラム 12 コー ド (分類)に限定されているので，できるだけ集計項目 を多くするため，時間量などはそのままの数量としてで はなく，すべて分布としてコードした。その結果，ある 幅をもった時間分布は表現できても，これらの平均值を 算出することは不可能になった。

\section{3. 調查対象世帯の性格}

本調查は, 既述した如く上層のホワイトカラーを有意 抽出しているので，調查対象世帯の性格は，いずれも集 合住宅居住世帯の上層階層の典型的特徴を示している。 $<$ 表 3-1>

以下その特徴を列挙すると次の様になる。

(1) 世带主の職業は, 全体として管理職の比重が最大 となるような上層ホワイトカラーである。ただ公団 賃貸の F.3 DK だけは，管理職，専門技術職，事 務職に 3 等分されている。主婦の場合は圧倒的に無 職が多いが，有職者は専門技術職が多い。

(2)世帯主の学歷は, 公団賃貸で, 高卒の比率が 30.4 \%でやや高いが,全体としては，大学卒が 70.4\%で 圧倒的である。主婦の場合は, 高卒と大学卆の比率 がほぼ逆転するが，それでも大学卆は公団賃貸で $18.9 \%$ ，全体で $27.8 \%$ に達する。

(3)世帯の手取り収入は，住宅規模とほぼ対応してい る。それぞれの世帯が全体の過半を占める収入額は， $\mathrm{F} \cdot 3 \mathrm{DK}$ で 10 万円以上, F.3 LD.K, P.3 LDK, $\mathrm{F} \cdot 3 \mathrm{LD} \cdot \mathrm{K}$ で 12 万円以上， M.4 DK で 14 万円以 上である。

(4) 家族形態は，全体としては夫婦家族で 4 人，第 1 子が小学校, 或はそれ以前というのが最も多い。た だ貨貸 F.3 DK には若い家族が多く, $3 \mathrm{LD} \cdot \mathrm{K}$ 及 び $4 \mathrm{DK}$ には成長した家族が多くなっている。従っ て, 末子は賃貸 $3 \mathrm{DK}$ で 1 2才, その他で $3 \sim 5$ 才 が最も多い。多くの家族は，いわばまだ子供から手 がはなせない状態にあるといえよう。

\section{4. 生活時間の算出方法}

家族生活や個人生活は，その時間量によって決定的な 影響を受ける。このため, 今回の生活時間の調查につい ては，世带票に家族全員の平日の行動別時間分布を記入 してもらい, coding の際に調查員が以下の方法で5つ の時間量を算出した。

まず個人の 1 日・ 24 時間の生活時間構造については <労働>一尽食時間を含む職場での拘束時間, <通勤> 一往復の通勤, 通学時間, <外出>一労働や通勤・通学 以外の外出時間，〈住戸>一睡眠を除いた住戸内に居る 時間, <睡眠>の 5 つに分類し, 次いでく住戸>をく食 事 $>,<$ <レビ>, <家事 >一育事, 身のまわり時間も含 む，＜新開，趣味>一読む，書く，趣味の仕事をする くその他>の 5 つの主たる行動別に分類した。なお「〜 しながら〜する」といった「ながら行動」の場合は, 後 の主たる「〜する」方の行動を採用した。

次にこれらの個人が，互いに家族としての関倸をも ち，集団生活を送るところから形成される時間として, 次の 4 つの時間量を算出した。

その第 1 は<家族時間>一家族全員が同一空閒に存在 している時間である。但しっこの場合 1 才末満の子供は 家族の一員として含めない。また睡眠時間も含めないも のとする。

第 2 は同じような意味での<夫婦時間〉である。第 3 は<父子時間>, 第 4 は<母子時閒>である。但し，< 父子時間 $>,<母 子$ 時間 $>$ 場合の子供は, 満 1 才以上 の子供が対象となり, その子供が複数の時は, 平均時間 を採用した（例えば，父が第 1 子と 3 時間，第 2 子と 1 時間接した時のく父子時間〉はこれを平均した 2 時間と なる)。

なお, 調查票の有効, 無効の判定は, 各々の時間量の 算出に必要な時間が記入されているかいないかによっ た。また今回の調查は, 平日と休日の比較を目的とせ ず, 平日のみの調査であるため, 出張, 入院, 里帰り等 の特殊な場合を除いて, 残りは全て有効とした。このた め,たまたま調查日が休日である対象者はく労働>が零 となっている。

\section{1 日・24 時間の個人の生活時間構造}

既に調查対象世帯の性格のところで述べているよう 
象世带 の性 格

\begin{tabular}{|c|c|c|c|c|c|c|c|c|c|c|c|c|c|c|c|c|c|c|c|c|c|c|c|c|c|}
\hline \multicolumn{2}{|c|}{ 職 } & \multicolumn{2}{|c|}{ 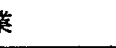 } & \multicolumn{5}{|c|}{ 主 娪 獞 業 } & \multicolumn{9}{|c|}{ 手取り世费収入（万円） } & \multicolumn{4}{|c|}{ 主带主学楚 } & \multicolumn{4}{|c|}{ 主婦学㷊 } \\
\hline $\begin{array}{l}\text { 現 } \\
\text { 場 } \\
\text { 労 } \\
\text { 㑘 }\end{array}$ & 営 & 無 & 不 & $\begin{array}{l}\text { 専 } \\
\text { 門 } \\
\text { 職 }\end{array}$ & $\begin{array}{l}\text { 事 } \\
\text { 務 } \\
\text { 職 }\end{array}$ & $\begin{array}{l}\text { 内 } \\
\text { 職 }\end{array}$ & 家 & 不 & 6 & $\begin{array}{l}6 \\
?\end{array}$ & $\begin{array}{l}8 \\
1\end{array}$ & $\begin{array}{l}10 \\
?\end{array}$ & $\begin{array}{c}12 \\
?\end{array}$ & $\begin{array}{c}14 \\
l\end{array}$ & $\begin{array}{c}16 \\
?\end{array}$ & $\begin{array}{c}18 \\
?\end{array}$ & $\begin{array}{l}\text { 不 } \\
\text { 明 }\end{array}$ & $\begin{array}{l}\text { 中 } \\
\text { 旧 } \\
\text { 小 } \\
\text { 卒 }\end{array}$ & $\begin{array}{l}\text { 高 } \\
\text { 昌 } \\
\text { 卒 }\end{array}$ & $\begin{array}{l}\text { 大 } \\
\text { 学 } \\
\text { 卒 }\end{array}$ & 不 & $\begin{array}{l}\text { 中 } \\
\text { 昌 } \\
\text { 崒 }\end{array}$ & $\begin{array}{l}\text { 高 } \\
\text { 皇 } \\
\text { 卒 }\end{array}$ & $\begin{array}{l}\text { 大 } \\
\text { 学 } \\
\text { 卒 }\end{array}$ & 不 \\
\hline
\end{tabular}

\begin{tabular}{|l|r|r|r|r|r|r|r||r|r|r|r|r|r|r|r|r|r|r|r|r|r|r|r|r|r|r|r|r|r|}
\hline 7 & 26 & 5 & 57 & 38 & 11 & 2 & 577 & 41 & 75 & 60 & 176 & 110 & 64 & 51 & 18 & 52 & 63 & 13 & 132 & 385 & 139 & 25 & 377 & 176 & 99 \\
\hline
\end{tabular}

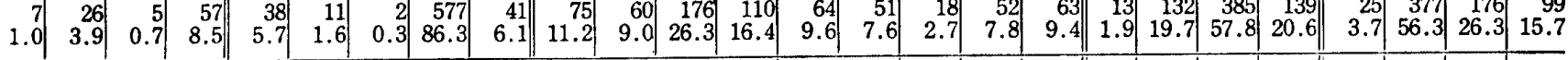

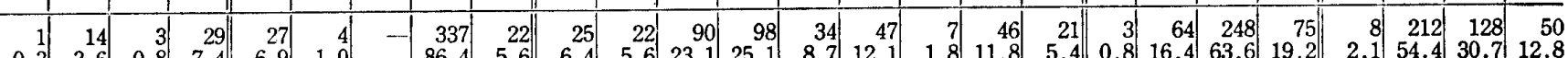

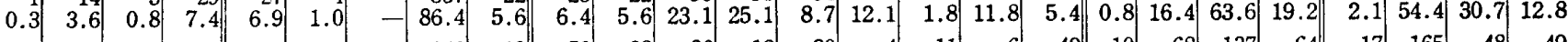

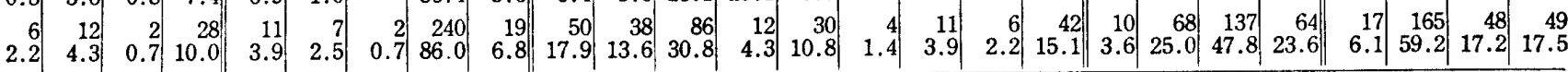

〈表 5-1 > 個人分布

\begin{tabular}{|c|c|c|c|c|}
\hline 性 & 秸 婚 & 労 & 年 令 & 人 数 $(\%)$ \\
\hline \multirow{6}{*}{ 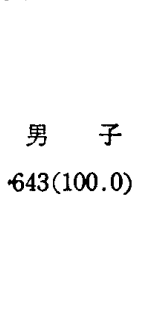 } & \multirow{2}{*}{$\begin{array}{l}\text { 未 婚 } \\
88(13.7)\end{array}$} & 有 職 & & $32 \quad(5.0)$ \\
\hline & & 無 職 & & $56 \quad(8.7)$ \\
\hline & \multirow{4}{*}{$\begin{array}{l}\text { 既＼cjkstart婚 } \\
555(86.3)\end{array}$} & \multirow{4}{*}{ 有 } & $20 \sim$ & $32 \quad(5.0)$ \\
\hline & & & $30 \sim$ & $318 \quad(49.5)$ \\
\hline & & & $40 \sim$ & $140 \quad(21.8)$ \\
\hline & & & $50 \sim$ & $65 \quad(10.1)$ \\
\hline \multirow{7}{*}{$\begin{array}{c}\text { 女 子 } \\
736(100.0)\end{array}$} & \multirow{2}{*}{$\begin{array}{l}\text { 未 媒 } \\
78(10.6)\end{array}$} & 有 & & $30 \quad(4.1)$ \\
\hline & & 無 & & $48 \quad(6.5)$ \\
\hline & \multirow{5}{*}{$\begin{array}{l}\text { 既 婚 } \\
658(89.4)\end{array}$} & 有 渞 & & $77 \quad(10.5)$ \\
\hline & & \multirow{4}{*}{$\begin{array}{l}\text { 無 職 } \\
581(78.9)\end{array}$} & $20 \sim$ & 144 (19.6) \\
\hline & & & $30 \sim$ & $298 \quad(40.5)$ \\
\hline & & & $40 \sim$ & $90 \quad(12.2)$ \\
\hline & & & $50 \sim$ & $49 \quad(6.7)$ \\
\hline
\end{tabular}

飞, 今回の調査対象者は, その中で幾分かの格差はみら れるものの, 基本的には上層ホワイトカラーの均一階層 とみなせる。従って, 個人票を単位とする集計は, 職業 については考慮せず, 男女, 年令, 未既婚, 有無職を基 礎とした次のような 13 タイプの分類によって行った。
く表 5-1>（ただし個人票は 15 才以上の成人であるか ら, 当然その中に学生が含まれるが, 未婚の無職者とし て分類されたタイプは，殆んど学生であると考えてよい から，職業別分類は採用しなかった)。

なお，本調查結果を全国的傾向と比較するため，昭和 40 年の NHK 国民生活時間調查を可能な限り 再編成し て用いた。

\section{5-1 既婚男子}

<表 5-2〜 5>に基いて，まず一般的な傾向を述べる

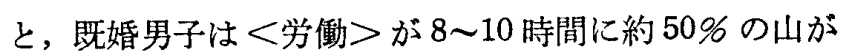
あるが，10 時間以上という 長時間労働が $35 \%$ もあるこ とは注目すべき現象である。<通勤〉は往復 2 3 時間 が $60 \%$ 近くで平均的な值であるが，<外出>は零に近 く, <住戸 >は 4 時間未満で $36 \%, 6$ 時間末満で約 $80 \%$ になる。<睡眠>は 7 8 時間, <食事>は 1 2 時間, <新聞, 読書>はせいぜい 1 時間前後, <家事>は零に 近い。 $<\mathrm{TV}>$ は零が $1 / 3,2$ 時間末満で約 $80 \%$ となる。 疲労感の全くない者はわずか $30 \%$ にすぎず，約 $70 \%$ は なんらかの疲れを訴えており，その中の約 40\% は気疲 れである。しかしその疲労の程度は, 䚻宅してからの休 息で回復できる程度であり，それほどひどくはない。

<表 5-2 > 年代別労働時間分布, 住戸時開分布

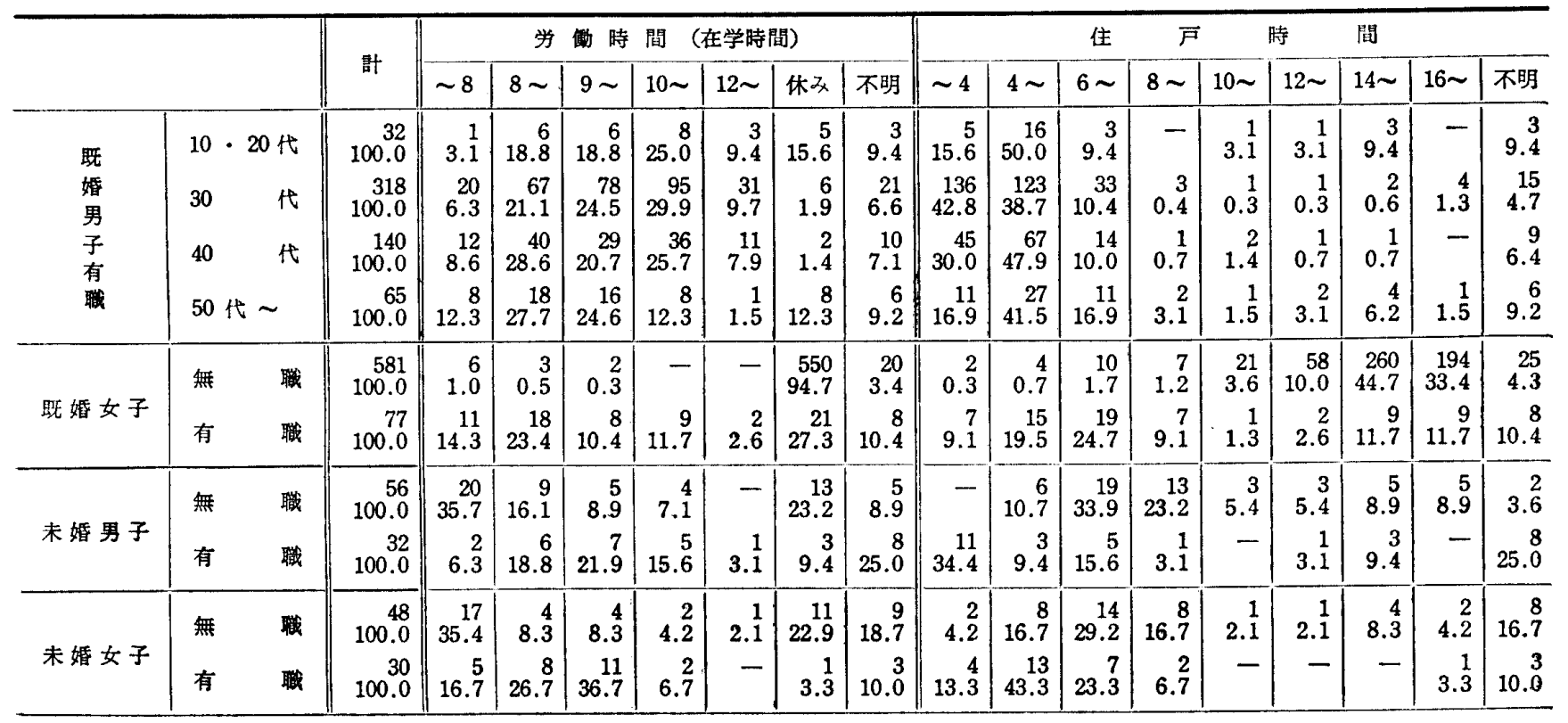


〈表 5-3〉 テレビ時間分布, 管事時間分布

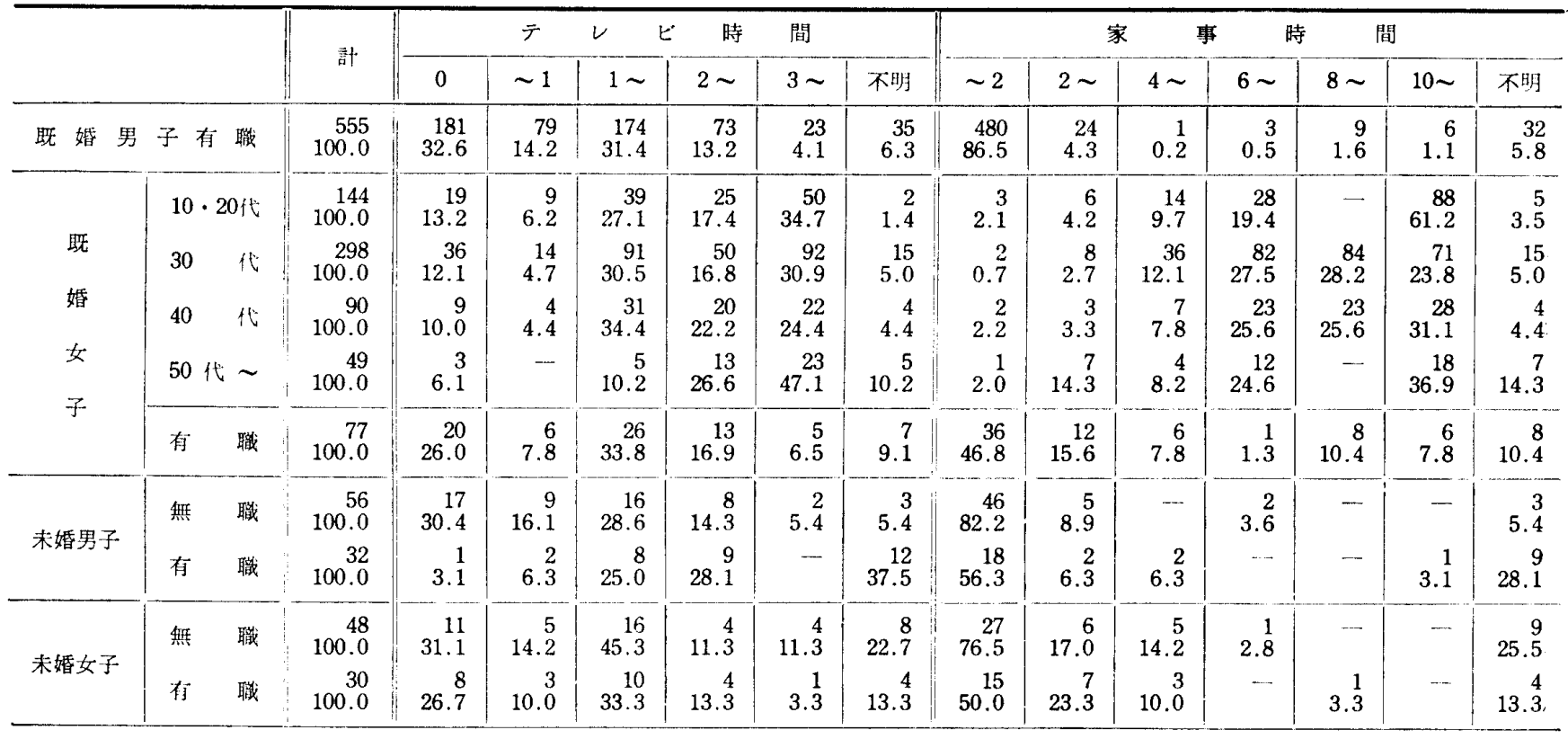

<表 5-4> 外出時間分布, 読書時間分布

\begin{tabular}{|c|c|c|c|c|c|c|c|c|c|c|c|c|c|}
\hline & & & \multirow{2}{*}{ 計 } & \multicolumn{2}{|r|}{ 外 } & 暲 & \multicolumn{2}{|l|}{ 闃 } & \multicolumn{2}{|r|}{ 読 } & 詩 & \multicolumn{2}{|l|}{ 開 } \\
\hline & & & & 0 & $\sim 1$ & $1 \sim$ & $2 \sim$ & 不 明 & 0 & $\sim 1$ & $1 \sim$ & $2 \sim$ & 不明 \\
\hline 睡 婚 男子 & 有 联 & 職 & $\begin{array}{r}555 \\
100.0\end{array}$ & $\begin{array}{r}390 \\
70.3\end{array}$ & $\begin{array}{r}15 \\
2.7\end{array}$ & $\begin{array}{r}40 \\
7.2\end{array}$ & $\begin{array}{r}55 \\
9.9\end{array}$ & $\begin{array}{r}35 \\
6.3\end{array}$ & $\begin{array}{r}162 \\
29.2\end{array}$ & $\begin{array}{r}149 \\
26.8\end{array}$ & $\begin{array}{r}120 \\
21.6\end{array}$ & $\begin{array}{r}84 \\
15.1\end{array}$ & $\begin{array}{r}40 \\
7.2\end{array}$ \\
\hline \multirow{2}{*}{ 既 婚女子 } & 無 眮 & & $\begin{array}{r}581 \\
100.0\end{array}$ & $\begin{array}{r}72 \\
12.4\end{array}$ & $\begin{array}{r}41 \\
7.1\end{array}$ & $\begin{array}{r}307 \\
52.8\end{array}$ & $\begin{array}{r}135 \\
23.2\end{array}$ & $\begin{array}{r}26 \\
4.5\end{array}$ & $\begin{array}{r}255 \\
43.9\end{array}$ & $\begin{array}{r}66 \\
11.4\end{array}$ & $\begin{array}{r}95 \\
16.3\end{array}$ & $\begin{array}{r}126 \\
21.7\end{array}$ & $\begin{array}{r}29 \\
5.0\end{array}$ \\
\hline & 有 眲 & 職 & $\begin{array}{r}77 \\
100.0 \\
\end{array}$ & $\begin{array}{r}42 \\
54.6 \\
\end{array}$ & $\begin{array}{r}8 \\
10.4\end{array}$ & $\begin{array}{r}13 \\
16.9\end{array}$ & $\begin{array}{r}7 \\
9.1 \\
\end{array}$ & $\begin{array}{r}7 \\
9.1 \\
\end{array}$ & $\begin{array}{r}37 \\
48.1 \\
\end{array}$ & $\begin{array}{r}10 \\
13.0 \\
\end{array}$ & $\begin{array}{r}10 \\
13.0 \\
\end{array}$ & $\begin{array}{r}13 \\
16.9\end{array}$ & 9.7 \\
\hline \multirow{2}{*}{ 末婚男子 } & 無 徏 & & $\begin{array}{r}56 \\
100.0\end{array}$ & $\begin{array}{r}42 \\
75.0\end{array}$ & $\begin{array}{r}2 \\
3.6\end{array}$ & $\begin{array}{r}4 \\
7.1\end{array}$ & $\begin{array}{r}3 \\
5.4\end{array}$ & $\begin{array}{r}5 \\
8.9\end{array}$ & $\begin{array}{r}3 \\
5.4\end{array}$ & $\begin{array}{r}2 \\
3.6\end{array}$ & $\begin{array}{r}6 \\
10.7\end{array}$ & $\begin{array}{r}43 \\
76.8\end{array}$ & $\begin{array}{r}2 \\
3.6\end{array}$ \\
\hline & 有 㬈 & 識 & $\begin{array}{r}32 \\
100.0\end{array}$ & $\begin{array}{r}12 \\
37.5\end{array}$ & $\cdots$ & $\begin{array}{r}8 \\
25.0\end{array}$ & $\begin{array}{r}4 \\
12.5\end{array}$ & $\begin{array}{r}8 \\
25.0\end{array}$ & $\begin{array}{r}16 \\
50.0\end{array}$ & 6.2 & $\begin{array}{r}3 \\
9.4\end{array}$ & 6.2 & 28.1 \\
\hline \multirow{2}{*}{ 未婚女子 } & 無 猶 & & $\begin{array}{r}48 \\
100.0\end{array}$ & $\begin{array}{r}31 \\
64.6\end{array}$ & $\begin{array}{r}2 \\
4.2\end{array}$ & $\begin{array}{r}3 \\
6.2\end{array}$ & $\begin{array}{r}4 \\
8.3\end{array}$ & $\begin{array}{r}8 \\
16.7\end{array}$ & $\begin{array}{r}7 \\
14.6\end{array}$ & $\begin{array}{r}1 \\
2.1\end{array}$ & $\begin{array}{r}7 \\
14.6\end{array}$ & $\begin{array}{r}25 \\
52.1\end{array}$ & $\begin{array}{r}8 \\
16.7\end{array}$ \\
\hline & 有 僟 & & $\begin{array}{r}30 \\
100.0\end{array}$ & $\begin{array}{r}21 \\
70.0\end{array}$ & 6.2 & 6.2 & 6.2 & $\begin{array}{r}3 \\
10.0\end{array}$ & $\begin{array}{r}14 \\
46.7\end{array}$ & $\begin{array}{r}3 \\
10.0\end{array}$ & $\begin{array}{r}4 \\
13.3\end{array}$ & $\begin{array}{r}6 \\
20.0\end{array}$ & $\begin{array}{r}3 \\
10.0\end{array}$ \\
\hline
\end{tabular}

<表 5-5> 年代別疲学度

\begin{tabular}{|c|c|c|c|c|c|c|c|}
\hline & & & 計 & 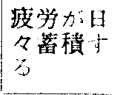 & 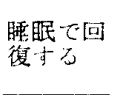 & 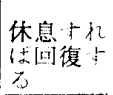 & 不 明 \\
\hline \multicolumn{3}{|c|}{ 計 } & $\begin{array}{r}1379 \\
100.0\end{array}$ & $\begin{array}{r}72 \\
5.2\end{array}$ & $\begin{array}{l}123 \\
8.9\end{array}$ & $\begin{array}{r}672 \\
48.7\end{array}$ & $\begin{array}{r}512 \\
37.2\end{array}$ \\
\hline \multirow{5}{*}{$\begin{array}{l}\text { 既 } \\
\text { 婚 } \\
\text { 有 } \\
\text { 職 } \\
\text { 男 } \\
\text { 子 }\end{array}$} & 小 & 計 & $\begin{array}{r}555 \\
100.0\end{array}$ & $\begin{array}{r}48 \\
8.6\end{array}$ & $\begin{array}{r}76 \\
13.7\end{array}$ & $\begin{array}{r}260 \\
46.8\end{array}$ & $\begin{array}{r}171 \\
30.9\end{array}$ \\
\hline & \multicolumn{2}{|c|}{$10 \cdot 20$ 代 } & $\begin{array}{r}32 \\
100.0\end{array}$ & $\begin{array}{r}1 \\
3.1\end{array}$ & $\begin{array}{r}6 \\
18.8\end{array}$ & $\begin{array}{r}14 \\
43.8\end{array}$ & $\begin{array}{r}11 \\
34.4\end{array}$ \\
\hline & & & $\begin{array}{r}318 \\
100.0\end{array}$ & $\begin{array}{r}38 \\
11.9\end{array}$ & $\begin{array}{r}36 \\
11.3\end{array}$ & $\begin{array}{r}144 \\
45.3\end{array}$ & $\begin{array}{r}100 \\
31.5\end{array}$ \\
\hline & & 代 & $\begin{array}{r}140 \\
100.0\end{array}$ & $\begin{array}{r}6 \\
4.3\end{array}$ & $\begin{array}{r}25 \\
17.9\end{array}$ & $\begin{array}{r}71 \\
50.7\end{array}$ & $\begin{array}{r}38 \\
29.2\end{array}$ \\
\hline & \multicolumn{2}{|c|}{50 代 } & $\begin{array}{r}65 \\
100.0\end{array}$ & $\begin{array}{r}3 \\
4.6\end{array}$ & $\begin{array}{r}9 \\
13.8\end{array}$ & $\begin{array}{r}31 \\
49.7\end{array}$ & $\begin{array}{r}22 \\
33.8\end{array}$ \\
\hline \multirow{2}{*}{$\begin{array}{l}\text { 既 } \\
\text { 婚 } \\
\text { 芓 }\end{array}$} & & 職 & $\begin{array}{r}581 \\
100.0\end{array}$ & $\begin{array}{r}14 \\
2.4\end{array}$ & $\begin{array}{r}30 \\
5.2\end{array}$ & $\begin{array}{r}287 \\
49.4\end{array}$ & $\begin{array}{r}250 \\
42.0\end{array}$ \\
\hline & & 職 & $\begin{array}{r}77 \\
100.0\end{array}$ & $\begin{array}{r}4 \\
5.2\end{array}$ & $\begin{array}{r}7 \\
9.1\end{array}$ & $\begin{array}{r}44 \\
57.1\end{array}$ & $\begin{array}{r}22 \\
28.6\end{array}$ \\
\hline \multirow{2}{*}{$\begin{array}{l}\text { 未 } \\
\text { 潩 } \\
\text { 等 }\end{array}$} & & 職 & $\begin{array}{r}56 \\
100.0\end{array}$ & $\begin{array}{r}3 \\
5.4\end{array}$ & $\begin{array}{r}2 \\
3.6\end{array}$ & $\begin{array}{r}20 \\
35.7\end{array}$ & $\begin{array}{r}31 \\
55.4\end{array}$ \\
\hline & & 職 & $\begin{array}{r}32 \\
100.0\end{array}$ & $\begin{array}{r}1 \\
3.1\end{array}$ & $\begin{array}{r}4 \\
12.5\end{array}$ & $\begin{array}{r}17 \\
53.1\end{array}$ & $\begin{array}{r}10 \\
31.3\end{array}$ \\
\hline \multirow{2}{*}{$\begin{array}{l}\text { 米 } \\
\text { 婚 } \\
\text { 李 }\end{array}$} & 無 & 職 & $\begin{array}{r}48 \\
100.0\end{array}$ & $\begin{array}{r}2.2 \\
2.1\end{array}$ & $\begin{array}{r}2 \\
4.2\end{array}$ & $\begin{array}{r}28 \\
58.3\end{array}$ & $\begin{array}{r}17 \\
35.4\end{array}$ \\
\hline & & 職 & $\begin{array}{r}30 \\
100.0\end{array}$ & $\begin{array}{r}1 \\
3.3\end{array}$ & 6.2 & $\begin{array}{r}16 \\
53.3\end{array}$ & $\begin{array}{r}11 \\
36.6\end{array}$ \\
\hline
\end{tabular}

次に年代による差をみると，〈睡眠〉,<家事〉,<そ の他〉は，年代による差はみられないが，〈住戸>が 30 代に特に少い。これは他の年代に比べて，<労働>が. 長いにもかかわらず，〈外出>も結構あるのでその影響 と考えられる。<食事 $>,<\mathrm{TV}>$ の比較的ゆたかなの は，10, 20 代 (以下 20 代という) と 50 代であり，30 代. はこれらの時間も短かく, 長時間労働のひずみが，家庭 生活の各時間の減少として顕著である。20 代では<労， 㗢>が長いにもかかわらずく食事〉, <TV>が多いの は，家庭での生活にウエイトをおいていると考えられ， 又 50 代ではく労働〉の短縮分がく住戸〉にとり入れら れて, 年代の高い 40,50 代ほどく食事 $>,<\mathrm{TV}>$ など はゆたかになってゆく。

NHK 時間調查との違いは, 20 代, 50 代の<学働> が, NHK の場合 8〜9 時間であって, 今回の調查の 10 . 〜12 時間の方が著しく長いこと，<TV>が特に若い世 代に NHKの方が長く出ていることである。しかし， <TV>が年代の高くなるにつれて比重が大きくなるの

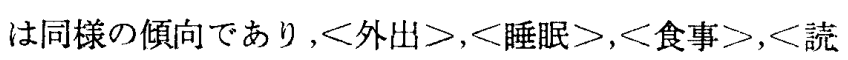


一書〉などは，全く酷似した結果が出ている。

疲労感恃若い20 代で肉体的疲労感がつよい。30 代で 恃铍労感を訴える者が $3 / 4$ に達し, 各年代層の中で最高 であり，かつその疲労が蓄積すると答えている者が多い ことが注目される。40 代以上は年代が高くなるにつれ て疲学感は減少し, 疲等度も軽度なものになってゆくの は<学㗢>の短縮と密接なつながりが感じられる。

\section{5-2 既 婚 女子}

既婚無職女子の一般的傾向は，1 2 時間の<外出> を除いては（これは殆んど買物のために使われている） 14 時間以上の<住戸>が約 $80 \%$ を占めているように， 殆んど 1 日中家の中で過していることである。しかし， <睡眠〉は 7 時間末満が $35 \%$ もあり，男子より 1 時間 ほど短くなっている。く食事〉は昼食時間も含まれてい るので， 2 時間以上が $80 \%$ と多く，<TV>は 1 2 時 と 3 時間以上に 2 つの山がある。<家事>は 6 時間以上 が殆んどで, 10 時間以上というのも $1 / 3$ 程度ある。し かしく住戸>の約 70\% を家事についやしている一方， 《読書〉などは零に近い。疲労感男子に比べて著しく 低く，半分以上が疲れないと答えており，疲労度も休息 で殆んど回復できる程度である。

次に年代別の 特徽としては, 20 代の<家事>が著し く長いこと（10 時間以上が大半を占める。 30 代になる と 6〜10 時間に中心が移る)，40 代あたりからく食事〉 がふえはじめること，50 代の<TV>が長いこと（3 時 閒以上が約 $1 / 2)$ などである。これは子供の世話で手が いっぱいという20 代の状態から，ややゆとりができて 大食事 >や<TV > に時間をまわせる 40,50 代への変化 を反映していると考えられる。

また女子は全般的に疲学感は少いが，年代が高くなる 上男子とは逆に疲労感が高くなり，体力の衰えがより直 接的に反映している。

NHK 時間調查との相違点は， NHK の方がくTV> が長いこと，〈食事〉が極端に短いことである。特に <食事〉は NHK の平均值 1 時間 20 分にくらべて, 本 調査では 2〜3 時間をもつものが50\%を越える。これは 本調查に於て，炊事，後片ゔけがく食事>の中に含まれ て記入されているとも考えられるがそれれにしても NHK の平均值よりはるかに長いことから，この階層で は「ゆっくり食事をする」慣習が形成されていることを 侗がわせる。

しかしく睡眠〉,<外出〉，<読書〉などは同様であ り，<TV>の年代による增減はよく似た傾句を示す。

有職婦人の場合く労働〉は8〜9時間にピークがある が 8 時間末満も多く, 男子にくらべてく労働〉は短い。 しかも有職者 77 名の中 21 名が調查当日は零であるよう に，その就業形態はパートなどの臨時的なものもかなり 多いと考えられる。く通勤〉は 2 3 時間, く外出>は
零が多いが，主婦が仕事につくことの影䭗はく家事〉に 最もよくあらわれ，2 時間末満が $1 / 2$ 強を占める。この ような時間的制約から<TV>は $1 / 3$ ， <読書>は $1 / 2$ 強が零よなっている。

また有職才娽の疲学感は非常に高く，約 $1 / 3$ 弱が肉体 的精神的両闻の疲学感男子以上に訴えている。

\section{5 -3 未婚男女}

末婚者は無職（学生が多い）と有職者では明らかに異 なっているが，学生の場合，男女の差は少ない。く住 戸〉は大体 6〜8 時間で比較的長く，その中でく読書〉 に $2 / 3 \sim 3 / 4$ が 2 時閒以上とっている。また女子の場合 でもく家事〉は全く零に近く，学生層は一般男女の中で も特異な時間構造をもっているといえよう。

有職者で注男女差がかなりみられ，男子が比較的自由 にく外出〉を楽しんでいる一方，女子の方はく家事〉に かなりの時間をさかなければならない状況にある。く読 書>などは，男女共既婚者なみに零に近くなる。

なお, 学生, 有職者をとわず, 未婚者注疲篎感は感じ ていない。

\section{5-4 個人時間保有意識}

このような 1 日の時閒構造の中で，各個人が個人生活 をするに足るだけの時間をもっているかどうかについて の主観的な判断をみると，全体的には，現在く敏日一応 ある>とは思っているものの，これからはくふやしたい フという積極的な態度をもっている。しかし男子だけを 取り出してみると，現在はく休日にしかない>ので今後 くふやしたい〉という希望がつよい。

保有意識は，年代よりもく住户〉との関係がつよく， く住韭〉が唇いほど，個人時間をもっていると感じてい る者が多い。とくにく住戸>の 4 時間を境として，くあ る>と考える比率がくない〉と答える比摔より高くな る。一方 8 時間以上にもなるとく今のままでよい>が過 半数に達するが，これは主として，来婚の学生層に限ら れるようである。

女子はく住戸〉が全体的に多いために，く十分〉<毎 日一忘>が常に多数を占めていて，8時間以上になると その比率が極端に高くなる。これは例えまとまった時間 がとれなくとも，家事のあい閒に個人生活老楽しむゆ上 りがあることの反映であろう。

有職女子は, 半数近くが個人生活の時間が不足してい ると感じている。

今後の希望については, 男子の場合, 個人時間をも, ている層ほどくふやしたい〉という希望がつよく，むた ない層ほどく今のままでよいつという答えが返ってきて いる。こうした点でく住戸>の少ない既婚 30 代はあき らめの気持がつよい。しかし今後，時間に余裕ができれ ばできるほど，個人生活への欲求は加速度的に高まって くるものと考えられる。 
<表 5-6> 男女別, 住户時間量別, 個人時間保有意識

\begin{tabular}{|c|c|c|c|c|c|c|c|c|c|c|}
\hline & & \multicolumn{5}{|c|}{ 現在の保有意識 } & \multicolumn{4}{|c|}{ これか.らの希望 } \\
\hline & 計 & $\begin{array}{l}\text { 毎 } \\
\text { 日 } \\
+ \\
\text { 分 }\end{array}$ & 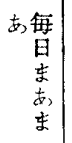 & $\begin{array}{l}\text { 休 } \\
\text { 日 } \\
2 \\
\partial_{\text {人 }}\end{array}$ & $\begin{array}{c}\text { 休 } \\
\text { 保 } \\
\text { 平平 } \\
\text { 日 }\end{array}$ & 明 & 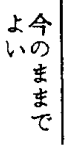 & 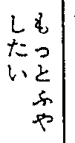 & 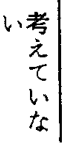 & 不 \\
\hline 男子訫 & $\begin{array}{r}600 \\
100.0\end{array}$ & $\begin{array}{r}104 \\
17.3\end{array}$ & $\begin{array}{r}188 \\
31.3\end{array}$ & $\begin{array}{r}209 \\
34.8\end{array}$ & $\begin{array}{r}89 \\
14.8\end{array}$ & \begin{tabular}{r||}
10 \\
1.7
\end{tabular} & $\begin{array}{r}217 \\
36.2\end{array}$ & $\begin{array}{r}324 \\
54.0\end{array}$ & $\begin{array}{r}40 \\
6.7\end{array}$ & $\begin{array}{r}19 \\
3.2\end{array}$ \\
\hline$\sim 2$ & $\begin{array}{r}38 \\
100.0\end{array}$ & $\begin{array}{r}4 \\
10.5\end{array}$ & $\begin{array}{r}6 \\
15.8\end{array}$ & $\begin{array}{r}17 \\
44.7\end{array}$ & $\begin{array}{r}11 \\
29.0\end{array}$ & - & $\begin{array}{r}10 \\
26.3\end{array}$ & $\begin{array}{r}24 \\
63.2 \\
\end{array}$ & $\begin{array}{r}2 \\
5.3 \\
\end{array}$ & 5.3 \\
\hline $2 \sim$ & $\begin{array}{r}170 \\
100.0\end{array}$ & $\begin{array}{r}11 \\
6.5\end{array}$ & $\begin{array}{r}50 \\
29.4\end{array}$ & $\begin{array}{r}70 \\
41.2\end{array}$ & $\begin{array}{r}35 \\
20.6\end{array}$ & $\begin{array}{r}4 \\
2.4\end{array}$ & $\begin{array}{r}52 \\
30.6\end{array}$ & $\begin{array}{r}103 \\
60.6\end{array}$ & $\begin{array}{r}13 \\
7.6\end{array}$ & $\begin{array}{r}2 \\
1.2\end{array}$ \\
\hline $4 \sim$ & $\begin{array}{r}242 \\
100.0\end{array}$ & $\begin{array}{r}34 \\
14.0\end{array}$ & $\begin{array}{r}79 \\
32.6\end{array}$ & $\begin{array}{r}92 \\
38.0\end{array}$ & $\begin{array}{r}32 \\
13.2\end{array}$ & $\begin{array}{r}5 \\
2.1\end{array}$ & $\begin{array}{r}87 \\
35.9\end{array}$ & $\begin{array}{r}130 \\
53.7\end{array}$ & $\begin{array}{r}17 \\
7.0\end{array}$ & $\begin{array}{r}8 \\
3.3\end{array}$ \\
\hline$\sim$ & $\begin{array}{r}85 \\
100.0\end{array}$ & $\begin{array}{r}23 \\
27.0\end{array}$ & $\begin{array}{r}34 \\
40.0\end{array}$ & $\begin{array}{r}19 \\
22.3\end{array}$ & $\begin{array}{r}8 \\
9.4\end{array}$ & $\begin{array}{r}1.2 \\
1.2\end{array}$ & $\begin{array}{r}34 \\
40.0\end{array}$ & $\begin{array}{r}43 \\
50.6\end{array}$ & $\begin{array}{r}5 \\
5.9\end{array}$ & $\begin{array}{r}3 \\
3.5\end{array}$ \\
\hline $8 \sim$ & $\begin{array}{r}65 \\
100.0\end{array}$ & $\begin{array}{r}32 \\
49.2\end{array}$ & $\begin{array}{r}19 \\
29.2\end{array}$ & $\begin{array}{r}11 \\
16.9\end{array}$ & $\begin{array}{r}3 \\
4.6\end{array}$ & - & $\begin{array}{r}34 \\
52.2\end{array}$ & $\begin{array}{r}24 \\
36.9 \\
\end{array}$ & $\begin{array}{r}3 \\
4.6 \\
\end{array}$ & $\begin{array}{r}4 \\
6.2\end{array}$ \\
\hline 女子計 & $\begin{array}{r}696 \\
100.0\end{array}$ & $\begin{array}{r}230 \\
33.1\end{array}$ & $\begin{array}{r}301 \\
43.3\end{array}$ & $\begin{array}{r}46 \\
6.6\end{array}$ & $\begin{array}{r}112 \\
16.1\end{array}$ & $\begin{array}{r}7 . \\
1.0\end{array}$ & $\begin{array}{r}340 \\
48.9\end{array}$ & $\begin{array}{r}294 \\
42.2\end{array}$ & $\begin{array}{r}32 \\
4.6\end{array}$ & $\begin{array}{r}30 \\
4.3\end{array}$ \\
\hline$\sim 6$ & $\begin{array}{r}55 \\
100.0\end{array}$ & $\begin{array}{r}8 \\
14.5\end{array}$ & \begin{tabular}{|r|}
20 \\
36.4
\end{tabular} & $\begin{array}{r}16 \\
29.1\end{array}$ & $\begin{array}{r}10 \\
18.2\end{array}$ & $\begin{array}{r}1 \\
1.8\end{array}$ & $\begin{array}{r}16 \\
29.1 \\
\end{array}$ & $\begin{array}{r}33 \\
60.0\end{array}$ & $\begin{array}{r}4 \\
7.3\end{array}$ & $\begin{array}{r}2 \\
3.6\end{array}$ \\
\hline $6 \sim$ & $\begin{array}{r}99 \\
100.0\end{array}$ & $\begin{array}{r}24 \\
24.2\end{array}$ & $\begin{array}{r}48 \\
48.5\end{array}$ & $\begin{array}{r}11 \\
11.1\end{array}$ & $\begin{array}{r}14 \\
14.1\end{array}$ & $\begin{array}{r}2 \\
2.0\end{array}$ & $\begin{array}{r}45 \\
45.5\end{array}$ & $\begin{array}{r}45 \\
45.5\end{array}$ & $\begin{array}{r}4 \\
4.0\end{array}$ & $\begin{array}{r}5 \\
5.1\end{array}$ \\
\hline $12 \sim$ & $\begin{array}{r}335 \\
100.0\end{array}$ & $\begin{array}{r}122 \\
36.4\end{array}$ & $\begin{array}{r}145 \\
43.3\end{array}$ & $\begin{array}{r}12 \\
3.6\end{array}$ & $\begin{array}{r}53 \\
15.8\end{array}$ & $\begin{array}{r}3 \\
0.9\end{array}$ & $\begin{array}{r}173 \\
51.6\end{array}$ & $\begin{array}{r}128 \\
38.2\end{array}$ & $\begin{array}{r}16 \\
4.8\end{array}$ & $\begin{array}{r}18 \\
5.4\end{array}$ \\
\hline $16 \sim$ & $\begin{array}{r}207 \\
100.0\end{array}$ & $\begin{array}{r}76 \\
36.7\end{array}$ & $\begin{array}{r}88 \\
42.5\end{array}$ & $\begin{array}{r}7 \\
3.4\end{array}$ & $\begin{array}{r}35 \\
16.9\end{array}$ & \begin{tabular}{r|}
1 \\
0.5
\end{tabular} & $\begin{array}{r}106 \\
51.2\end{array}$ & $\begin{array}{r}88 \\
42.5\end{array}$ & $\begin{array}{r}8 \\
3.9\end{array}$ & $\begin{array}{r}5 \\
2.4\end{array}$ \\
\hline
\end{tabular}

女子は<住戸>8 時間未満のものは要求度が高く, 〈ふやしたい>が $60 \%$ もある。8時間以上になると， くこのままでよい>が逆に 50〜60\%を占め, 無職既婚 者はその殆んどが現状に満足している。く表 5-6>

\section{6. 家族関係からみた生活時間構造}

家族生活は，家族がともに過す時間量によって規定さ れ，家族時間は，その家族の成医段階と世带主の㷌宅時 間によって規定される。ここでは, 前節でみたよらな特 㣤をむつ個人が互いに家族集団を形成寸るとき，そこに ぞれほどの家族時間，夫婦時間，父子時間，母子時間が 生みだされるかを明らかにしたい。

\section{6-1 家族時間量}

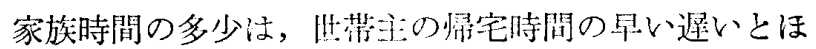
ぼ対応する。㖅宅時間が 午後 7 時以前々 7 8 時では家 族時間のモードは 3 時間以上，年後 8〜9時では 1 2 時間，午後 9〜11时では 1 時開末满，そして午後 11 時 以降は零となって, 午後 8 時以降は激減寸る。

これを家族の成長段階则にみると，子倛のない家族， 長子が中学生以上の家族, 辰子が学命前の家族, 長子が 小学生の家族の順で家族時間が減少し, 前の 3 者のモー ドが 3 時間以上であるのに，後者は 1 2 時間のところ になる。これは成長した家族では比校的世带主の帰宅が 早く，しか子子倛が荤くまで起きているのに対して，小 学生を長子とする家族では, 憎宅が逢い上に子供がはや くねてしまうためであると考えられる。

しかしながら全体としては，家族の成長段階のいかん に拘らず午後 9 時以降の㷌宅が $30 \%$ 近く存在すること が，家族時間にとっての大きな制約となっている。なお
<表 6-1> 世带主䚻宅時間別, 家族周期別, 家族時間量

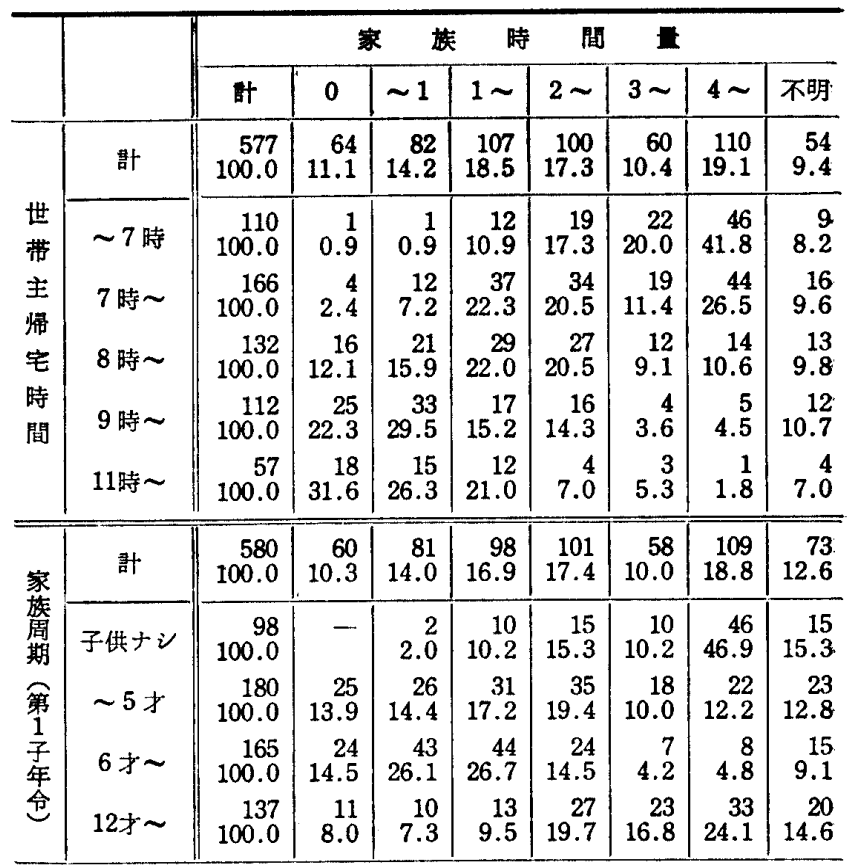

注：母数が異なるのは，各々の果計によって不明さ除く有效票数が異る ためである。

子供のない家族で家族時間が多いのは，家族時間が即ち 夫婦時間であることによる。く表 6-1>

\section{6-2 夫婦時間量}

同様に夫婦時間のモードも，世帯主の㷌宅時間が午後 7 時以前, 午後 7 時〜 8 時では 5 時間以上, 牛後 8 時〜 9 時では 4 5 時間, 午後 9 時 11 時では 2 3 時間, そして午後 11 時以降では 2 時間未満となる。

家族の成長段階別には，長子が中学生以上の家族，子 供のない家族, 辰子が学令前の家族, 長子が小学生の家 族の順で夫婦時間が減少する。<表 6-2>

\section{6-3 親子時間量}

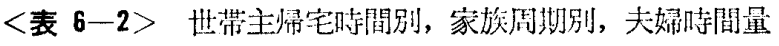

\begin{tabular}{|c|c|c|c|c|c|c|c|c|}
\hline & & 計 & $\sim 2$ & $2 \sim$ & $3 \sim$ & $4 \sim$ & $5 \sim$ & 不明 \\
\hline \multirow{6}{*}{$\begin{array}{l}\text { 世 } \\
\text { 带 } \\
\text { 主 } \\
\text { 婦 } \\
\text { 宅 } \\
\text { 時 } \\
\text { 閵 }\end{array}$} & 棓十 & $\begin{array}{r}574 \\
100.0\end{array}$ & $\begin{array}{r}58 \\
10.1\end{array}$ & $\begin{array}{r}83 \\
14.5\end{array}$ & $\begin{array}{r}113 \\
19.7\end{array}$ & $\begin{array}{r}139 \\
24.2\end{array}$ & $\begin{array}{r}168 \\
29.3\end{array}$ & $\begin{array}{r}13 \\
2.3\end{array}$ \\
\hline & $\sim 7$ 時 & $\begin{array}{r}110 \\
100.0\end{array}$ & -.. & $\begin{array}{r}4 \\
3.6\end{array}$ & $\begin{array}{r}99 \\
8.2\end{array}$ & $\begin{array}{r}19 \\
17.3\end{array}$ & $\begin{array}{r}74 \\
67.3\end{array}$ & $\begin{array}{r}4 \\
3.6\end{array}$ \\
\hline & 7 時 & $\begin{array}{r}164 \\
100.0\end{array}$ & $\begin{array}{r}1 \\
0.6\end{array}$ & $\begin{array}{r}7 \\
4.3\end{array}$ & $\begin{array}{r}26 \\
15.9\end{array}$ & $\begin{array}{r}56 \\
34.1\end{array}$ & $\begin{array}{r}72 \\
43.9\end{array}$ & 1.2 \\
\hline & 8 時 & $\begin{array}{r}131 \\
100.0\end{array}$ & $\begin{array}{r}7 \\
5.3\end{array}$ & $\begin{array}{r}15 \\
11.4\end{array}$ & $\begin{array}{r}40 \\
30.5\end{array}$ & $\begin{array}{r}49 \\
37.4\end{array}$ & $\begin{array}{r}16 \\
12.2\end{array}$ & 3.1 \\
\hline & 9 & $\begin{array}{r}112 \\
100.0\end{array}$ & $\begin{array}{r}24 \\
21.4\end{array}$ & $\begin{array}{r}37 \\
33.0\end{array}$ & $\begin{array}{r}29 \\
25.9\end{array}$ & $\begin{array}{r}14 \\
12.5\end{array}$ & $\begin{array}{r}5 \\
4.5\end{array}$ & $\begin{array}{r}3 \\
2.7\end{array}$ \\
\hline & 1. & $\begin{array}{r}57 \\
100.0\end{array}$ & $\begin{array}{r}26 \\
45.6\end{array}$ & $\begin{array}{r}20 \\
35.1\end{array}$ & $\begin{array}{r}9 \\
15.8\end{array}$ & $\begin{array}{r}1 \\
1.8\end{array}$ & $\begin{array}{r}1 \\
1.8\end{array}$ & - \\
\hline \multirow{5}{*}{$\begin{array}{l}\text { 家 } \\
\text { 族 } \\
\text { 期 } \\
\text { 第 } \\
1 \\
\text { 子 } \\
\text { 年 } \\
\text { 令 }\end{array}$} & 嗼 & $\begin{array}{r}577 \\
100.0\end{array}$ & $\begin{array}{r}57 \\
9.9\end{array}$ & $\begin{array}{r}76 \\
13.2\end{array}$ & $\begin{array}{r}106 \\
18.4\end{array}$ & $\begin{array}{r}132 \\
22.9\end{array}$ & $\begin{array}{r}167 \\
29.0\end{array}$ & $\begin{array}{r}39 \\
6.8\end{array}$ \\
\hline & 子体 & $\begin{array}{r}95 \\
100.0\end{array}$ & $\begin{array}{r}10 \\
10.5\end{array}$ & $\begin{array}{r}14 \\
14.7\end{array}$ & $\begin{array}{r}10 \\
10.5\end{array}$ & $\begin{array}{r}19 \\
20.0\end{array}$ & $\begin{array}{r}31 \\
32.6\end{array}$ & $\begin{array}{r}11 \\
11.6\end{array}$ \\
\hline & $\sim 5$ 水 & $\begin{array}{r}180 \\
100.0\end{array}$ & $\begin{array}{r}16 \\
8.9\end{array}$ & $\begin{array}{r}25 \\
13.9\end{array}$ & $\begin{array}{r}36 \\
20.0\end{array}$ & $\begin{array}{r}51 \\
28.3\end{array}$ & $\begin{array}{r}45 \\
25.0\end{array}$ & $\begin{array}{r}7 \\
3.9\end{array}$ \\
\hline & 6 求 & $\begin{array}{r}165 \\
100.0\end{array}$ & $\begin{array}{r}22 \\
13.3\end{array}$ & $\begin{array}{r}27 \\
16.4\end{array}$ & $\begin{array}{r}42 \\
25.5\end{array}$ & $\begin{array}{r}28 \\
17.0\end{array}$ & $\begin{array}{r}39 \\
23.6\end{array}$ & $\begin{array}{r}7 \\
4.2\end{array}$ \\
\hline & 12 才。 & $\begin{array}{r}137 \\
100.0\end{array}$ & $\begin{array}{r}9 \\
6.6\end{array}$ & $\begin{array}{r}10 \\
7.3\end{array}$ & $\begin{array}{r}18 \\
13.1\end{array}$ & $\begin{array}{r}34 \\
24.8\end{array}$ & $\begin{array}{r}52 \\
38.0\end{array}$ & $\begin{array}{r}14 \\
10.2\end{array}$ \\
\hline
\end{tabular}

\footnotetext{
*無夫婂家族は母数から除く。
} 
〈表 6-3> 世帯主帰宅時間別-家族期周別父子時間量

\begin{tabular}{|c|c|c|c|c|c|c|c|c|c|}
\hline & 部 & 0 & -1 & $1 \sim$ & $2 \sim$ & $\sim$ & $4 \sim$ & 不明 \\
\hline \multirow{6}{*}{$\begin{array}{l}\text { 世 } \\
\text { 带 } \\
\text { 主 } \\
\text { 㷌 } \\
\text { 宅 } \\
\text { 時 } \\
\text { 間 }\end{array}$} & 計 & & $\begin{array}{r}46 \\
9.8\end{array}$ & $\begin{array}{r}82 \\
17.5\end{array}$ & $\begin{array}{r}90 \\
9.2\end{array}$ & $\begin{array}{r}73 \\
15.6\end{array}$ & $\begin{array}{r}62 \\
13.2\end{array}$ & $\begin{array}{r}59 \\
12.6\end{array}$ & $\begin{array}{r}57 \\
12.2\end{array}$ \\
\hline & & & - & - & $\begin{array}{r}16 \\
8.6\end{array}$ & $\begin{array}{r}19 \\
22.1\end{array}$ & $\begin{array}{r}22 \\
25.6\end{array}$ & $\begin{array}{r}30 \\
34.9\end{array}$ & 10.5 \\
\hline & 7 時 & $\begin{array}{r}129 \\
100.0\end{array}$ & $\begin{array}{r}4 \\
3.1\end{array}$ & $\begin{array}{r}8 \\
6.2\end{array}$ & $\begin{array}{r}37 \\
28.7\end{array}$ & $\begin{array}{r}27 \\
20.9\end{array}$ & $\begin{array}{r}19 \\
14.7\end{array}$ & $\begin{array}{r}18 \\
14.0\end{array}$ & $\begin{array}{r}16 \\
12.4\end{array}$ \\
\hline & & $\begin{array}{r}115 \\
100.0\end{array}$ & $\begin{array}{r}12 \\
10.5\end{array}$ & $\begin{array}{r}23 \\
20.0\end{array}$ & $\begin{array}{r}25 \\
1.7\end{array}$ & $\begin{array}{r}21 \\
8.3\end{array}$ & $\begin{array}{r}17 \\
14.8\end{array}$ & 0.2 & $\begin{array}{r}11 \\
9.6\end{array}$ \\
\hline & & $\begin{array}{r}96 \\
100.0\end{array}$ & $\begin{array}{r}21 \\
21.9\end{array}$ & $\begin{array}{r}34 \\
35.4\end{array}$ & $\begin{array}{r}13 \\
13.5\end{array}$ & $\begin{array}{r}6 \\
6.2\end{array}$ & $\begin{array}{r}3 \\
3.1\end{array}$ & 4.2 & $\begin{array}{r}15 \\
15.6\end{array}$ \\
\hline & & $\begin{array}{r}43 \\
100.0\end{array}$ & $\begin{array}{r}9 \\
20.9\end{array}$ & $\begin{array}{r}17 \\
39.5\end{array}$ & $\begin{array}{r}9 \\
20.9\end{array}$ & - & 2.3 & 2.3 & $\begin{array}{r}6 \\
14.0\end{array}$ \\
\hline \multirow{4}{*}{ 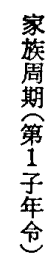 } & 計 & $\begin{array}{r}468 \\
100.0\end{array}$ & $\begin{array}{r}42 \\
9.0\end{array}$ & 5.9 & 7.9 & $\begin{array}{r}74 \\
15.8 \\
\end{array}$ & 13.0 & 13.5 & $\begin{array}{r}65 \\
13.9 \\
\end{array}$ \\
\hline & & $\begin{array}{r}169 \\
100.0\end{array}$ & $\begin{array}{r}20 \\
11.8\end{array}$ & $\begin{array}{r}25 \\
14.8\end{array}$ & $\begin{array}{r}33 \\
19.5\end{array}$ & $\begin{array}{r}29 \\
17.2\end{array}$ & $\begin{array}{r}15 \\
8.9\end{array}$ & $\begin{array}{r}16 \\
9.5\end{array}$ & $\begin{array}{r}31 \\
18.3 \\
\end{array}$ \\
\hline & & $\begin{array}{r}163 \\
100.0\end{array}$ & $\begin{array}{r}19 \\
11.7\end{array}$ & $\begin{array}{r}42 \\
25.8\end{array}$ & $\begin{array}{r}42 \\
25.8\end{array}$ & $\begin{array}{r}26 \\
15.9\end{array}$ & $\begin{array}{r}12 \\
7.4\end{array}$ & $\begin{array}{r}8 \\
4.9\end{array}$ & $\begin{array}{r}14 \\
8.6\end{array}$ \\
\hline & & $\begin{array}{r}136 \\
100.0\end{array}$ & $\begin{array}{r}3 \\
2.2\end{array}$ & 1 & 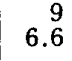 & $\begin{array}{r}19 \\
14.0\end{array}$ & $\begin{array}{r}34 \\
25.0\end{array}$ & $\begin{array}{r}39 \\
28.7\end{array}$ & $\begin{array}{r}20 \\
14.7\end{array}$ \\
\hline
\end{tabular}

*父, 子供（1才未满も含む）のいない家族は母数から除く。

* 世带主帰宝時間と家族周期とでは母数，分布が共に異るのはてそれぞ れの場合の有効票が異なるためである。

親子の接する時間の中でも，父子時間は愔帯主の帰宅 時間によって規定され，そのモードは午後 7 時以前で 3 時間以上, 午後 7 時 8 時間 では 1 2 時間, 午後 8 時 〜 9 時では 1 2 時間, 午後 9 時以降では 1 時間末満に なる。

これを家族の成長段階でみると，長子が学令前の家族 では 1 2 時間にモードがあり, 長子が 小学生の家族で は 1 時間未満と 1 2 時間に分れる。しかし長子が中学 生以上になると，子供が比較的遅く起きているため 3 時 間以上が压倒的な比重をもつにいたる。

一方母子時間は，主として末子の年令に大きく左右さ れるが，大体の傾向としては，長子が学令前の家族では そのモードが 6 時間以上, その他の家族では 4 時間未満 となって，父子時間よりもはるかに大きい值を示す。 <表6-3>

\section{6-4 家族時間保有意識}

〈表 6-4〉家族時間量別，家族時間保有意識（世崬主）

\begin{tabular}{|c|c|c|c|c|c|c|c|c|c|c|c|}
\hline & \multirow[b]{2}{*}{ 融 } & \multicolumn{6}{|c|}{ 現在の保有意識 } & \multicolumn{4}{|c|}{ ニれからの希皨 } \\
\hline & & $\begin{array}{l}\text { 每 } \\
\text { 日 } \\
\text { 十 } \\
\text { 分 }\end{array}$ & $\begin{array}{c}\text { 每 } \\
\text { 日 } \\
\text { ま } \\
\text { ప } \\
\text { ま }\end{array}$ & $\begin{array}{c}\text { 休 } \\
\text { 日 } \\
\sigma \\
z_{x}\end{array}$ & $\begin{array}{c}\text { 共平 } \\
\text { 日昌 } \\
\text { な休 } \\
\text { 日 }\end{array}$ & 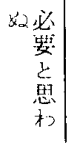 & 明 & 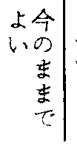 & 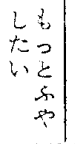 & $\begin{array}{c}\omega \\
\text { w } \\
2 \\
\tau \\
\omega \\
+\end{array}$ & 明 \\
\hline 摽 & $\begin{array}{r}530 \\
100.0\end{array}$ & $\begin{array}{r}65 \\
12.3\end{array}$ & $\begin{array}{r}210 \\
39.6\end{array}$ & $\begin{array}{r}226 \\
42.6\end{array}$ & $\begin{array}{r}21 \\
4.0\end{array}$ & $\begin{array}{r}4 \\
0.8\end{array}$ & $\begin{array}{r}4 \\
0.8\end{array}$ & $\begin{array}{r}255 \\
48.1 \\
\end{array}$ & $\begin{array}{r}223 \\
42.1 \\
\end{array}$ & $\begin{array}{r}35 \\
6.6 \\
\end{array}$ & $\begin{array}{r}17 \\
3.2 \\
\end{array}$ \\
\hline 0 & $\begin{array}{r}66 \\
100.0\end{array}$ & $\begin{array}{r}2 \\
3.0\end{array}$ & $\begin{array}{r}18 \\
27.3\end{array}$ & $\begin{array}{r}43 \\
65.1\end{array}$ & $\begin{array}{r}3 \\
4.5\end{array}$ & -1 & - & $\begin{array}{r}25 \\
37.9\end{array}$ & \begin{tabular}{|r|}
355 \\
53.0
\end{tabular} & 6.1 & 3.2 \\
\hline$\sim 1$ & $\begin{array}{r}82 \\
100.0\end{array}$ & $\begin{array}{r}3 \\
3.7\end{array}$ & $\begin{array}{r}20 \\
24.4\end{array}$ & $\begin{array}{r}50 \\
61.0\end{array}$ & $\begin{array}{r}7 \\
8.5\end{array}$ & $\begin{array}{r}1 \\
1.2\end{array}$ & $\begin{array}{r}1.2 \\
1.2\end{array}$ & $\begin{array}{r}30 \\
36.6\end{array}$ & $\begin{array}{r}44 \\
53.6\end{array}$ & $\begin{array}{r}6 \\
7.3\end{array}$ & $\begin{array}{r}2 \\
2.4\end{array}$ \\
\hline $1 \sim$ & $\begin{array}{r}108 \\
100.0\end{array}$ & 3.7 & $\begin{array}{r}41 \\
38.0\end{array}$ & $\begin{array}{r}57 \\
52.8\end{array}$ & $\begin{array}{r}5 \\
4.6\end{array}$ & - & $\begin{array}{r}1 \\
0.9\end{array}$ & $\begin{array}{r}43 \\
39.8 \\
\end{array}$ & $\begin{array}{r}54 \\
50.0\end{array}$ & $\begin{array}{r}7 \\
6.5\end{array}$ & $\begin{array}{r}4 \\
3.7\end{array}$ \\
\hline $2 \sim$ & $\begin{array}{r}102 \\
100.0\end{array}$ & $\begin{array}{r}9 \\
8.8\end{array}$ & $\begin{array}{r}47 \\
46.1\end{array}$ & $\begin{array}{r}39 \\
38.2\end{array}$ & $\begin{array}{r}3 \\
2.9\end{array}$ & $\begin{array}{r}3 \\
2.9\end{array}$ & $\begin{array}{r}1 \\
1.0\end{array}$ & $\begin{array}{r}55 \\
53.9\end{array}$ & $\begin{array}{r}39 \\
38.2\end{array}$ & $\begin{array}{r}5 \\
4.9\end{array}$ & $\begin{array}{r}3 \\
2.9\end{array}$ \\
\hline $3 \sim$ & $\begin{array}{r}63 \\
100.0\end{array}$ & $\begin{array}{r}12 \\
19.0\end{array}$ & $\begin{array}{r}28 \\
44.4 \\
\end{array}$ & $\begin{array}{r}20 \\
31.7\end{array}$ & $\begin{array}{r}2 \\
3.2\end{array}$ & - & $\begin{array}{r}1 \\
1.6\end{array}$ & $\begin{array}{r}28 \\
44.4\end{array}$ & $\begin{array}{r}28 \\
44.4\end{array}$ & $\begin{array}{r}4 \\
6.3\end{array}$ & $\begin{array}{r}3 \\
4.8\end{array}$ \\
\hline $4 \sim$ & $\begin{array}{r}169 \\
100.0\end{array}$ & $\begin{array}{r}35 \\
32.1\end{array}$ & $\begin{array}{r}56 \\
51.4\end{array}$ & $\begin{array}{r}17 \\
15.6\end{array}$ & $\begin{array}{r}1 \\
0.9\end{array}$ & $\ldots$ & -1 & $\mid \begin{array}{r}74 \\
67.9\end{array}$ & $\begin{array}{r}23 \\
21.1\end{array}$ & $\begin{array}{r}9 \\
8.3\end{array}$ & $\begin{array}{r}3 \\
2.8\end{array}$ \\
\hline
\end{tabular}

まず家族時間の現状に対する世帯主（或は主婦）の主 観的判断をみると，全体としては現状がく休日のみ> 43\%，〈毎日まあまあ>が 40\%，<毎日十分>が $12 \%$ であるが，今後の希望としてはくふやしたい>の $42 \%$ よりも，<このままでよい>が $48 \%$ と多数を占める。 家族時間量別にみると，家族時間が 2 時間未满のものま ではく毎日ある〉よりもく休日しかとれない〉ものが 上廻っているが，2 時間以上となると，前者が優位を占 める。このことから 2 時間あたりが家族時間の「毎日あ る・なし」の主観的判断の基準になっていることがわか る。

今後の希望も大体この 2 時間を境として分れ， 2 時間 未満ではくふやしたい>, 2 時間以上ではくこのままで よい>が各々優位を占める。しかしながら，2 時間未满 で 38\% の現状を肯定する者があること，2 時間以上で $33 \%$ の増加要求があることは, 家族時間付対する要求が その内容によって大きく異なることを示唆する。く表 6 $-4>$

\section{7. 結語}

個人の生活時間構造は, 各年代毎にその特徽を次のよ らにパターン化することができる。

\begin{tabular}{|c|c|c|c|}
\hline & & 男 & 女 \\
\hline 睡 & $\begin{array}{lrr}\sim & 20 & \text { 代 } \\
30 & & \text { 代 } \\
40 & \text { 代 } & \sim \\
\text { 有職女 } & \text { 子 }\end{array}$ & \begin{tabular}{l} 
家庭生活穓極型 \\
職 場 偏 重 型 \\
家庭生活再認識型 \\
\multicolumn{2}{c}{}
\end{tabular} & $\begin{array}{l}\text { 肙 胃 偏 重 型 } \\
\text { 家庭生活惯性型 } \\
\text { 家庭生活余裕型 } \\
\text { 家庭生活多忙型 }\end{array}$ \\
\hline 未 & $\begin{array}{l}\text { 無職(学生) } \\
\text { 有職 }\end{array}$ & $\begin{array}{l}\text { 住戸内佋 人生活型 } \\
\text { 住戸外個 人生活型 }\end{array}$ & $\begin{array}{l}\text { 住户内個 人生活型 } \\
\text { 家庭生活消極型 }\end{array}$ \\
\hline
\end{tabular}

（1） 10,20 代の男子は<労働〉が長いにも拘らず， く外出〉はできるだけ押えてく住戸>をとろう としており，家庭創生期に於る積極性を示してい る。女子は育児のために生活の大部分を費してお り，<家事>が既婚女子の中でもズバ抜けて银 w。

（2）30 代の男子は<労働>，<外出>に生活の重 点があり，その結果く住戸>は圧迫され，疲篎 度，疲労感上も高い。女子はく家事>がへって茫 干の時間的余裕をもつが，そのことによる特徽あ る変化はみられない。

（3）40 代以上になると，男子はく労働>の短縮分 をく住戸>にまわし，また女子も<家事〉のゆ とりができる結果，〈食事>, <TV>がふえて くる。

（4）有職女子はく学働>の影響によって，〈家事> が無職女子に比べて 1/3〜1/5になる。

（5） 未婚者の中でも無職（学生）の場合はく住戸> をたっぷりもっているが，有職者になると時間的 制約櫭婚者と殆んど変らなくなる。 
（6）男子はく住戸>が多くなればなるほどこれから 個人時間をく子やしたい〉とする 希望が強く， く住戸>が少い場合はくこのままでよい>とす る傾向の方がつよい。

（7）今回の調查対象者は, NHK 調査に扔けるホワ イトカラー層の全国平均とほぼ類似した時間構造 をもっている。

次に，これらの個人によって構成される家族の生活時 間の特徴を要約すると以下の如くなる。

(8) 家族全員, 或は父親と子供が接する時間量は, 抴帯主の帰宅時間によって大きく変動し, 特に子 供の小さい家族では午後 8 時までに帰るか帰らな いかはよってく家族時間〉やく父子時間>の量的 格差が大きい。しかし現実には午後 8 時以降帰宅 の家庭は 40〜50\% もある。
（9）<家族時間>は，子供のない家族（家庭創生期） に於てく夫婦時間>になるのでその他の段階の家 族に比べて最大となるが，以下，第 1 子が中学生 以上 (家庭成熟期)，学令前 (家庭拉大期), 小学 生（家庭成長期）の順でへっていく。後の 3 者の モードは 1〜2 時間である。

（10）<家族時間>をこれからくふやしたい〉とする 希望は，それが 2 時間末満のところで激増する が， 2 時間以上の家族でも $1 / 3$ は増加させたいと 希望をもっている。

\begin{tabular}{|c|c|c|c|c|}
\hline $\begin{array}{l}\text { 家 族 } \\
\text { 成段 }\end{array}$ & $\begin{array}{l}\text { 子供年令 } \\
\text { (第 } 1-5)\end{array}$ & $\begin{array}{c}\text { 家族時間犎 } \\
(乇-ト)\end{array}$ & 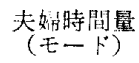 & $\begin{array}{c}\text { 父子時間量 } \\
(モ-ト)\end{array}$ \\
\hline 家庭創生期 & & 4 時間 & 5 時間 & - \\
\hline 家庭拡大期 & $0 \sim 5$ 好 & $2 \sim 3$ 時 間 & $4 \sim 5$ 時閒 & $1 \sim 2$ 時 閏 \\
\hline 家庭成長期 & $6 \sim 11$ 准 & $1 \sim 2$ 時間 & $3 \sim 4$ 㭙间 & ～ 1 時 間 \\
\hline 家庭成驇期 & 12 戈 & $2 \sim 3$ 時 閵 & 5 時閻 & 4 時間 \\
\hline
\end{tabular}


ANALYSIS OF THE HACHINOHE LIBRARY DAMAGED BY '68 TOKACHIOKI EARTHQUAKE

(See Page 57)

by TSUNEO OKADA, Assoc. Prof., Institute of Industrial Science, Univ. of Tokyo, MASAYA MURAKAMI, Assoc. Prof., Faculty of Eng., Univ. of Chiba, KUNIAKI UDAGAWA, Assistant, Faculty of Eng. Tokyo Metropolitan Univ., TAKAO NISHIKAWA, Assistant, Institute of Industrial Science, Univ. of Tokyo YUTAKA OSAWA, Prof., Earthquake Research Institute, Univ. of Tokyo and HISASHI TANAKA, Prof., Institute of Industrial Science Univ. of Tokyo. Members of A.I.J.

U.D.C. $69.022: 699.84: 624.043$

ELASTIC ANALYSIS OF SHEAR WALLS LOADED SYMMETRICALLY WITH REGARD TO THEIR LONGITUDINAL AND TRANSVERSAL CENTER LINE

-Part III - Numerical Results of an Example--

(See Page 59)

by Dr. MASAHIDE TOMII, Prot. of Kyushu Univ. and IKUO TOKUHIRO, Assistant of Kyushu Univ. Members of A.I.J.

U.D.C. $624.078 .072 .2: 624.043$

\section{LIMIT ANALYSIS OF BEAM-COLUMN CONNECTIONS (VIII-1)}

-Cruciform Connections of Wideflange Members Subjected to Strong-Axis Bending and Thrust on Column

(See Page 69)

by Dr. HISASHI TANAKA, Prof. Inst. of Indu. Sei. Univ. of Tokyo and YUNG CHUAN LINE, Graduate Student Univ, of Tokyo, Members of A.I.J.

U.D.C. 64.01

THE „TIME STUDY ON THE WHITE COLOURS' FAMILY LIFE AND PRIVATE ONES

(The Reserach of Home Circle, Part II)

by MORIAKI HIROHARA, Assist. of Kyoto Univ., SHUNPEI TAKEMOTO, Planner of Japan Housing Corporation and TETSUO MATSUBARA, Planner of Osaka Prefectural government, Members of A.I.J

The pattern of home circle is provided with family hours with which they spend together. The results of survey are as follows.

1. The family hours is decided with the husbands working hours.

2. The family of no child has relatively home circle hours.

3. The family of which first child is elder than seven yearsfold, has little home circle hours. Because the husband

is caused to work late at night on his business and his wife is engaged with daily sitting.

4. Old family recover its hours again and also its member has a little private hours.

5. The more the private hours they have, the more extend its needs. 